\title{
GAMBARAN PENGETAHUAN TENTANG TAMPILAN MALOKLUSI PADA SISWA SEKOLAH MENENGAH PERTAMA KRISTEN 67 IMANUEL BAHU
}

\author{
${ }^{1}$ Ahmad Djunaid, \\ ${ }^{2}$ Paulina N. Gunawan \\ ${ }^{3}$ Johanna A. Khoman \\ ${ }^{1}$ Mahasiswa Program Studi Kedokteran Gigi Fakultas Kedokteran \\ Universitas Sam Ratulangi Manado \\ ${ }^{2}$ Fakultas Kedokteran Universitas Sam Ratulangi Manado \\ ${ }^{3}$ Program Studi Kedokteran Gigi Fakultas Kedokteran \\ Universitas Sam Ratulangi Manado \\ Email: ahmad_djunaid@rocketmail.com
}

\begin{abstract}
Malocclusion is a condition that deviates from normal occlusion include irregularity of the teeth in the dental arch such as crowding, protrusif, malposition and harmonious relationship with the opposing teeth. Occurrence of malocclusion in children will lead to many problems such as including impaired of mastication, speech processing as well as aesthetic problems socially impaired. The purpose of this study to describe the knowledge of malocclusion in junior high school 67 Christian Immanuel Bahu. The research is descriptive and sampling method with a total sampling methods. Retrieval of data to find a picture of malocclusions knowledge gained by means of questionnaires by a sample of 88 students. Knowledge of the research lookscale photographs by AC of IOTN in accordance with the composition of his teeth with persentse $44.31 \%$, knowledge of tooth arrangement in accordance with the profile picture based on the percentage of $54.55 \%$ and a knowledge of treatment needs in accordance with the percentage of $23.87 \%$ appropriate Treatment needs.
\end{abstract}

Keywords: knowledge, malocclusion.

\begin{abstract}
Abstrak: Maloklusi merupakan keadaan yang menyimpang dari oklusi normal meliputi ketidakteraturan gigi-geligi dalam lengkung rahang seperti gigi berjejal, protrusif, malposisi maupun hubungan yang tidak harmonis dengan gigi antagonisnya. Terjadinya maloklusi pada anak akan mengakibatkan banyak masalah diantaranya gangguan pengunyahan, proses bicara serta masalah pergaulan karena estetik yang terganggu. Tujuan dari penelitian yaitu untuk mengetahui gambaran pengetahuan tentang maloklusi pada siswa SMP Kristen 67 Imanuel Bahu. Penelitian bersifat deskriptif dan cara pengambilan sampel dengan metode total sampling. Pengambilan data untuk mengetahui gambaran pengetahuan tentang maloklusi diperoleh dengan cara pengisian kuesioner oleh sampel yang berjumlah 88 siswa. Hasil penelitian didapatkan data pengetahuan tampilan berdasarkan skala fotograf AC dari IOTN sesuai dengan susunan giginya dengan persentse 44,31\%, pengetahuan tentang susunan gigi sesuai berdasarkan foto profil dengan persentase $54,55 \%$ dan pengetahuan tentang kebutuhan perawatan dengan persentase $23,87 \%$ sesuai dengan kebutuhan perawatan.
\end{abstract}

Kata kunci: pengetahuan, maloklusi.

Kesehatan gigi dan mulut pada anak-anak merupakan faktor penting yang harus diperhatikan sedini mungkin, oleh sebab itu pengetahuan kepada anak khusunya pengetahuan tentang maloklusi harus lebih diperhatikan karena jika anak mengalami maloklusi dapat mempengaruhi pertumbuhan gigi pada usia selanjutnya. Maloklusi merupakan keadaan yang menyimpang dari oklusi normal meliputi ketidakteraturan 
gigi-geligi dalam lengkung rahang seperti gigi berjejal, protrusif, malposisi maupun hubungan yang tidak harmonis dengan gigi antagonisnya. Secara garis besar terjadinya maloklusi dipengaruhi oleh faktor turunan dan faktor lingkungan. Maloklusi pada anak dapat mengakibatkan banyak masalah seperti kesulitan saat berbicara, gangguan pengunyahan serta masalah pergaulan karena estetik yang terganggu. Hal ini dapat terjadi jika tidak dilakukan tindakan pencegahan dini pada anak. Pencegahan dini dapat dilakukan dengan cara memberikan pengetahuan kepada masyarakat secara luas tentang penyebab terjadinya maloklusi khususnya pada anak-anak. ${ }^{1,2}$

Petugas klinis, pasien dan keluarga mungkin memiliki penilaian yang berbedabeda terhadap maloklusi apakah harus dirawat atau tidak. Hal inilah yang mendasari dibuatnya suatu standar penilaian terhadap kebutuhan perawatan yaitu IOTN (Index Of Orthodontic Treatment Need). Standar penilaian tersebut telah disepakati secara internasional karena metode ini valid, dapat dipercaya dan mudah digunakan. ${ }^{3}$

Penelitian Faruk di Indonesia tahun 2007 pada pelajar Sekolah Dasar dengan jumlah 118 anak menunjukkan bahwa memiliki pengetahuan tentang maloklusi 34,57\% dari jumlah sampel. Hasil ini juga didukung oleh penelitian yang dilakukan Aikins di Nigeria tahun 2012 pada anak sekolah usia 12-18 tahun meunjukan bahwa pengetahuan anak tentang maloklusi $82,5 \%$ dari jumlah sampel. ${ }^{4,5}$

Berdasarkan hasil survey di atas, penulis ingin melakukan penelitian tentang gambaran pengetahuan tentang tampilan maloklusi pada siswa Sekolah Menengah Pertama Kristen 67 Imanuel Bahu, dengan tujuan khusus penelitian untuk mengetahui gambaran pengetahuan tentang tampilan maloklusi berdasarkan skala fotograf, berdasarkan susunan gigi dan berdasarkan kebutuhan perawatan maloklusi.

\section{BAHAN DAN METODE}

Penelitian ini merupakan penelitian deskriptif dengan desain cross sectional.
Jumlah sampel yang diteliti berjumlah 88 orang diambil dengan teknik total sampling.

Pengumpulan data diperoleh melalui survei dilapangan. Siswa dibagikan informed consent untuk kesediaan sebagai subjek penelitian. Langkah selanjutnya ialah beberapa pertanyaan sesuai pertanyaan dari kuesioner dan dilakukan foto susunan gigi dalam keadaan oklusi sentrik. Selanjutnya data diolah berdasarkan tabel distribusi dan disajikan berdasarkan hasil persentase.

\section{HASIL}

Penelitian ini dilakukan di SMP Kristen 67 Imanuel Bahu pada tanggal 18-25 maret 2013 dengan jumlah sampel 88 orang berdasarkan kriteria inklusi dan eksklusi.

Berdasarkan karakteristik subjek penelitian jumlah siswa laki-laki 42 orang dan siswa perempuan sebanyak 46 orang (Tabel 1).

Tabel 1. Distribusi berdasarkan jenis kelamin

\begin{tabular}{lcc}
\hline Jenis kelamin & $\begin{array}{c}\text { Jumlah } \\
\text { (siswa) }\end{array}$ & $\mathbf{\%}$ \\
\hline Perempuan & 46 & 52,27 \\
Laki-laki & 42 & 47,73 \\
Total & 88 & 100 \\
\hline
\end{tabular}

Gambaran pengetahuan tentang tampilan maloklusi pada siswa SMP Kristen 67 Imanuel Bahu. Hasil penelitian dapat dilihat pada Tabel 2-4.

Hasil penelitian meunjukkan bahwa sebagian besar pilihan siswa tidak sesuai berdasarkan pertanyaan gambar dari skala fotograf dari IOTN dengan susunan gigi siswa berjumlah 49 orang $(55,69 \%)$ dari total sampel (Tabel 2).

Hasil penelitian meunjukkan bahwa sebagian besar pilihan siswa benar berdasarkan jawaban dari pertanyaan dengan foto dari susunan gigi siswa berjumlah 49 orang (54,55\%) dari total sampel (Tabel 3).

Hasil penelitian meunjukkan bahwa sebagian besar pilihan siswa salah berdasarkan pertanyaan dengan susunan gigi siswa berjumlah 67 orang $(76,13 \%)$ dari total sampel (Tabel 4). 
Tabel 2. Distribusi siswa tentang pengetahuan tampilan maloklusi berdasarkan sesuai tidaknya gambar skala fotograf AC dari IOTN dengan susunan gigi siswa.

\begin{tabular}{cccccc}
\hline & & \multicolumn{3}{c}{ Jawaban Tentang Tampilan } \\
Jenis & Jumlah & \multicolumn{4}{c}{ Maloklusi } \\
\cline { 3 - 6 } Kelamin & Siswa & Sesuai & $\%$ & $\begin{array}{c}\text { Tidak } \\
\text { sesuai }\end{array}$ & $\%$ \\
\hline L & 42 & 17 & 40,47 & 25 & 59,53 \\
P & 46 & 22 & 47,82 & 24 & 52,18 \\
Total & 88 & 39 & 44,31 & 49 & 55,69 \\
\hline
\end{tabular}

Tabel 3. Distribusi siswa tentang pengetahuan tampilan maloklusi berdasarkan kerapian susunan giginya dengan foto profil.

\begin{tabular}{cccccc}
\hline \multirow{2}{*}{$\begin{array}{c}\text { Jenis } \\
\text { Kelamin }\end{array}$} & \multirow{2}{*}{$\begin{array}{c}\text { Jumlah } \\
\text { Siswa }\end{array}$} & \multicolumn{4}{c}{ Jawaban Tentang Tampilan } \\
\cline { 3 - 6 } & & Maloklusi \\
\hline L & 42 & 25 & 59,52 & 17 & 40,48 \\
P & 46 & 23 & 50 & 23 & 50 \\
Total & 88 & 48 & 54,55 & 40 & 45,45 \\
\hline
\end{tabular}

Tabel 4. Distribusi siswa tentang pengetahuan tempilan maloklusi berdasarkan kebutuhan perawatan maloklusi.

\begin{tabular}{cccccc}
\hline \multirow{2}{*}{$\begin{array}{c}\text { Jenis } \\
\text { Kelamin }\end{array}$} & \multirow{2}{*}{ Jumlah } & \multicolumn{4}{c}{$\begin{array}{c}\text { Jawaban Tentang Tampilan } \\
\text { Maloklusi }\end{array}$} \\
\cline { 3 - 6 } & Siswa & \multicolumn{4}{c}{$\%$} \\
\cline { 3 - 6 } & 42 & 10 & 23,8 & 32 & 76,2 \\
$\mathrm{~L}$ & 46 & 11 & 23,91 & 35 & 76,09 \\
$\mathrm{P}$ & 46 & 21 & 23,87 & 67 & 76,13 \\
Total & 88 & 21 & & &
\end{tabular}

\section{BAHASAN}

Distribusi pengetahuan siswa tentang tampilan berdasarkan skala fotograf (Tabel 2) menunjukkan bahwa lebih banyak pilihan siswa yang tidak sesuai setelah dinilai berdasarkan foto dari susunan giginya sebanyak 49 orang dengan persentase 55,69\%. Penilaian ini menggambarkan bahwa laki-laki lebih banyak menjawab tidak sesuai yaitu 25 orang dari total siswa laki-laki dengan persentase 59,53\%.

Dilihat dari hasil penelitian bahwa penilaian siswa tentang tampilan pada dirinya masih kurang, hal ini berdasarkan penilaian siswa terhadap giginya apakah sesuai atau tidak sesuai dengan pilihan jawaban pada gambar skala fotograf dari
IOTN. Siswa berpendapat bahwa pilihan gambar pada skala fotograf dengan susunan giginya telah sesuai akan tetapi terdapat 49 orang yang salah memilih. Hasil penilaian diperoleh dengan cara mencocokkan foto susunan gigi dengan pilihan gambar dari siswa, terdapat lebih banyak ketidaksesuaian siswa laki-laki dalam menentukan pilihanya. Hasil dari data digambarkan bahwa siswa mengerti bahwa susunan giginya dikatakan rapi akan tetapi didalam penilaian dengan mencocokan foto susunan gigi dengan pilihan siswa pada gambar sesuai susunan giginya dengan skala fotograf terdapat ketidaksesuaian pada saat memilih gambar 1, 2 dan 3.

Distribusi berdasarkan foto susunan gigi (Tabel 3) menunjukkan bahwa siswa sebagian besar menjawab benar sebanyak 48 orang dengan persentase 54,55\%. Hal ini tidak berbeda jauh dengan penelitian Aikins di Nigeria pada tahun 2012 tentang pengetahuan maloklusi pada anak sebagian besar berpengetahuan tentang maloklusi sebanyak $82,5 \%{ }^{5}$

Data hasil penelitian dari (Tabel 3) menyatakan bahwa dari jumlah sampel lakilaki yang menjawab sesuai sebanyak 25 orang dengan persentase $59,52 \%$ dan dari jumlah sampel perempuan yang menjawab sesuai sebanyak 23 orang dengan persentase $50 \%$. Hasil penelitian diperoleh dengan penilaian skala fotograf, dimana peneliti melihat kembali hasil jawaban dari siswa dalam menentukan pilihan gambar sesuai susunan giginya kemudian dinilai dengan jawaban siswa berdasarkan pertanyaan dan didapat hasil lebih banyak yang menjawab benar pengetahuannya berdasarkan susunan giginya. Data dari tabel 3 menyatakan bahwa siswa laki-laki lebih banyak menjawab benar dikarenakan kekeliruan siswa menentukan jawaban pada pilihan gambar skala fotograf yang sesuai dengan susunan giginya lebih banyak pada gambar 1, 2 dan 3. Hal inilah yang membuat siswa laki-laki lebih menonjol hasilnya dibandingkan dengan siswa perempuan.

Distribusi berdasarkan pengetahuan kebutuhan perawatan (Tabel 4) menunjukkan bahwa siswa yang memilih tidak sesuai 
lebih banyak yaitu 67 orang dengan persentase 76,13\% dan yang sesuai yaitu 21 orang dengan persentase 23,87\%. Hal ini tidak berbeda jauh dengan penelitian Aikins di Nigeria pada tahun 2012 tentang pengetahuan maloklusi pada anak sebagian kecil dari jumlah sampel berpengetahuan tentang kebutuhan perawatan maloklusi sebanyak $35,1 \%{ }^{5}$

Data hasil penelitian pada Tabel 4 menunjukkan bahwa lebih banyak siswa yang menjawab tidak sesuai yaitu 67 orang (76,13\%). Hal ini dikarenakan lebih banyak siswa dengan susunan giginya sesuai pada gambar 1-4 pada skala fofograf dari IOTN namun memilih jawaban perlu perawatan. peneliti merasa hal ini dikarenakan siswa kurang memahami bentuk perawatan maloklusi sehingga menganggap perawatan karies juga termasuk didalam perawatan maloklusi.

Setelah dilakukannya penelitian, peneliti memberi penjelasan kembali kepada siswa benar tidaknya pilihan gambar maupun pilihan jawaban pada kuesionernya, hal ini dilakukan dengan tujuan agar tingkat pengetahuan maloklusi siswa lebih baik.

\section{SIMPULAN}

Pengetahuan tentang tampilan berdasarkan susunan gigi dengan menggunakan skala fotograf dari IOTN pada siswa SMP Kristen Imanuel Bahu di dapatkan hasil bahwa siswa yang menjawab sesuai susunan giginya dengan skala fotograf berjumlah 39 orang $(44,31 \%)$.

Pengetahuan tentang tampilan berdasarkan susunan gigi dengan foto profilnya pada siswa SMP Kristen Imanuel Bahu didapatkan hasil bahwa siswa yang menjawab sesuai dengan susunan giginya dengan foto profil susunan giginnya dengan menggunakan skala fotograf berjumlah 48 orang (54,55\%).

Pengetahuan tentang tampilan berdasarkan kebutuhan perawatan dengan skala fotograf pada siswa SMP Kristen Imanuel Bahu di dapatkan hasil bahwa siswa yang menjawab sesuai dengan susunan giginya dengan menggunakan skala fotograf berdasarkan kebutuhan perawatan berjumlah 21 orang $(23,87 \%)$.

\section{SARAN}

Diharapkan pihak sekolah dapat membuat kegiatan Usaha Kesehatan Gigi Sekolah yang didalamnya dijalankan program pembelajaran tentang kesehatan gigi dan mulut khususnya pengetahuan tentang maloklusi pada siswa dan dijalankan secara rutin.

Diharapkan kepada guru dan orang tua lebih memperhatikan upaya-upaya kesehatan dengan cara pemberian pengetahuan yang lebih tentang kesehatan gigi dan mulut khususnya pengetahuan tentang tampilan maloklusi pada anak. Diharapkan kepada selanjutnya untuk dapat melakukan penelitian lebih lanjut dengan dilakukannya suatu tindakan pemeriksaan khususnya pada siswa-siswi yang mengalami maloklusi.

\section{DAFTAR PUSTAKA}

1. Bishara SE. text book of orthodontics. Philadelphia: Elsevier, 2001; p.83-95.

2. Dewi O. Analisis hubungan maloklusi dengan kualitas hidup pada remaja SMU kota Medan tahun 2007 [Tesis]. Medan: Program parcasarjana Universitas Sumatera Utara pascasarjana; 2008.

3. Grzywacz I. The value of the Aesthetic Componen of the IOTN [serial online]. 2003 [cited 2013 Feb 15]. Available from URL: www.ncbi.nlm.nih.gov/pubmed/12608724.

4. Hoesin F. Indikator kebutuhan perawatan ortodonsia (IKPO) sebagai instrumen perencanaan pelayanan ortodonsia. Indonesian Journal of Dentistry. 2007:238.

5. Aikins EA, Dacosta OO, Onyeaso CO, Isiekwe MC. Self-perseption of maloklusi among Nigeria adolescents using the Aesthetic Componen of the IOTN. The Open Dentistry Journal. 2012:61-3. 